\title{
Population dynamics of Pulsatilla patens (L.) Mill. in a new locality in Poland
}

\author{
Marek Tadeusz Ciosek*, Katarzyna Piórek, Roman Sikorski \& Agata Trębicka
}

Faculty of Natural Science, Siedlce University of Natural Sciences and Humanities, B. Prusa 12, 08-110 Siedlce, Poland

*corresponding author (e-mail: marekc@uph.edu.pl)

\begin{abstract}
A new locality of Pulsatilla patens (L.) Mill. in the Wyszków-Jegiel Forest District, in the southern part of Puszcza Biała (ATPOL EC79) is described. This locality is situated on an escarpment, at the edge of Peucedano-Pinetum fresh pine forest with elements of Serratulo-Pinetum mixed pine forest and Potentillo albae-Quercetum steppe oak forest. Good light conditions prevail in the place of plant occurrence. Studies carried out in 2008-2015 showed an increasing trend of $P$. patens population, though, recently, this population seems to be stable. The number of species accompanying the pasque-flower also increased in this time period. It was found based on the analysis of flora directly neighbouring the clumps of the pasque-flower. During 7 years, the number of taxa increased by $31.5 \%$ on plot I and by $25 \%$ on plot II. In the years $2011-2013$, the pasqueflower was represented both by flowering (1-2) and vegetative individuals. Afterwards, the plant was present only in vegetative stage. The number of its leaves varied in time. The highest number of leaves - 14 per individual - was noted in 2014, and the lowest number (1) - in 2012. The reason for a decline in the number of plant clumps in the site Dalekie and, at the same time, the greatest threat was the excavation of sand from the escarpment. In 2012, this escarpment slid down and several clumps of the pasque-flower were destroyed. Forest management and digging up by wild boars were additional factors limiting the population. To preserve the site of $P$. patens, measures of active protection should be applied.
\end{abstract}

Key words: Pulsatilla patens, Wyszków Forest District, population dynamics, protection

\section{Introduction}

The pasque-flower (Pulsatilla patens (L.) Mill.) is a hemicryptophyte of circumpolar range (Meusel et al. 1965). Its range covers sub-polar areas of Europe, Asia and North America. In Poland, the plant was present in 453 sites (Zając \& Zając 2001). The centre of its range is in the north-east, from where as many as 238 sites were reported. Most numerous populations are also located there (Wójtowicz 2000). The plant is rarer in Polish lowlands and uplands, where populations are composed of a few individuals. Sites in western and south-western part of Poland are still rarer (Chmura 2003). Occurrences reported earlier from Podhale and Pieniny have not been confirmed in recent years. Populations of the pasque-flower from eastern Germany (Röder \& Kiehl 2006). Wójtowicz (2000) is of the opinion that European border of the range of the pasque-flower runs across Poland and its optimum is in eastern Poland (Fig. 1).
P. patens is a valuable and increasingly rare element of Polish flora. Since 1958, it was subject to strict conservation and, since 2004, the species has been actively protected. The pasque-flower is considered endangered in Poland and in many European countries. It is considered critically endangered in the Polish Red List of Vascular Plants (Zarzycki \& Szelag 2006) and endangered in the Polish Red Data Book of Plants (Pawlikowski \& Wójtowicz 2014). Regionally, it has a status of vulnerable species in Pomorze Zachodnie (Żukowski \& Jackowiak 1995), endangered species in Pomorze Gdańskie (Markowski \& Buliński 2004) and critically endangered in Wielkopolska (Jackowiak et al. 2007). In Nizina Południowopodlaska, the pasqueflower is enlisted as extinct (Głowacki et al. 2003). In Europe, the plant is listed as endangered species, e.g. in Slovakia, Lithuania, Latvia, Estonia, Finland, Sweden, Russia, the Czech Republic and in Germany. The pasque-flower is included in Annex I to the Bern 


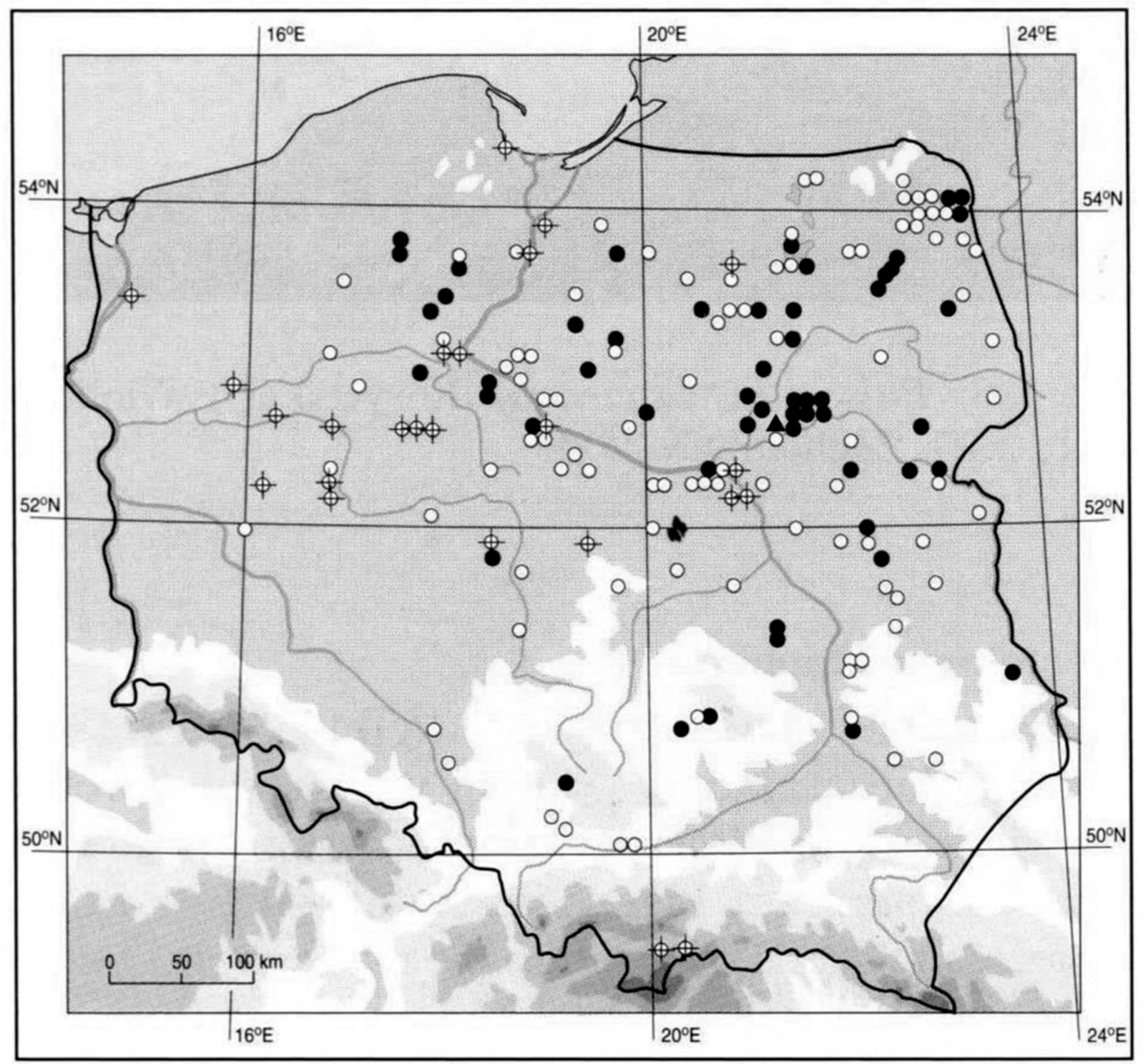

Fig. 1. Distribution of Pulsatilla patens in Poland (Wójtowicz 2001)

Explanations: $\bullet-$ present sites, $\boldsymbol{\phi}$ - historical sites, where the species is now absent, $\circ-$ natural sites not confirmed after $1980, \boldsymbol{\Lambda}-$ new locality

Convention and in Annexes II and IV to the Habitat Directive of EU (1992).

In Poland, $P$. patens is a differential species of Peucedano-Pinetum pine forests (Matuszkiewicz 2006). Less frequently, it can be found at edges of Serratulo-Pinetum, Querco roboris-Pineum mixed pine forests or Potentillo albae-Quercetum steppe oak forests (Juśkiewicz-Swaczyna 2010a, 2010b; Łaska \& Sienkiewicz 2010; Pawlikowski 2011). It grows in sheltered places with southern or south-western exposition (Ciosek 1999; Zych 2007), on acidic sandy soils of low nitrogen, phosphorus, magnesium and potassium content (Wójtowicz 2000).

Sites of the pasque-flower in Puszcza Biała were situated in nine ATPOL squares (Fig. 1). Out of 46 sites in this area, 35 were reported from Forest District Ostrów Mazowiecka and surrounding forests (Ciosek 1985, 1990, 1995a, 1995b, 1999). The last survey carried out in 2009 allowed to verify the occurrence of the pasque-flower in the area. Its presence was confirmed in only five sites of the district; three in Turka forest region and one in each of Nagoszewa and Brzostowa forest regions. The pasque-flower started to decline also in other parts of Puszcza Biała. The aim of this study was to present population dynamics of $P$. patens in a new site in Dalekie near Wyszków in years 2008-2015.

\section{Study species}

The study area is situated near Dalekie, north of Wyszków in Masovian Province. Pulsatilla paten grows in a pine forest in Forest District Wyszków-Jegiel, in southern part of Puszcza Biała (ATPOL square EC79). According to physical-geographical division of Poland (Kondracki 2013), the area is situated in Nizina Północnomazowiecka, mesoregion Międzyrzecze Łomżyńskie. This is a fragment of morainic upland situated between the valleys of the lower Narew River and the lower Bug River. According to biological-sylvan regionalization (Trampler et al. 1990), the study area belongs to mesoregion Wysoczyzna Łomżyńska, region Nizina Podlaska and Wysoczyzna Siedlecka, which are parts of IV Land Mazowiecko-Podlaska.

Wyszków surroundings are situated inside the range of the central upland climate of Podlasie Region (Romer 1949). Puszcza Biała and its neighbourhood have cli- 
matic conditions of the continental type. Mean annual air temperature is $7.7^{\circ} \mathrm{C}$, annual precipitation sum -550 $\mathrm{mm}$ and snow cover lasts 50 to 80 days. Westerly and south-westerly winds prevail there. Vegetation period lasts from 200 to 220 days.

\section{Material and methods}

Studies on the population of P. patens were carried out in years 2008-2015. The number of individuals, flowering individuals and leaves was determined every year. To estimate changes in communities with the pasque-flower, phytosociological relevés with the commonly used Braun-Blanquet method were made every third year (2008, 2011 and 2014). Moreover, two $2 \times 2 \mathrm{~m}$ study plots were established among clumps of the pasque-flower. In each of them, detailed floristic lists were made in years 2008 and 2014 and the occurrence frequency of particular species was estimated in a 5-grade scale (1 - very rare, 1-2 individuals, 2 - rare, several individuals, 3 - fairly frequent, ten to twenty individuals, 4 - frequent, several dozen individuals, 5 - very frequent - several dozen to several hundred individuals). Based on these data, the dynamics and competitiveness of species accompanying the pasque-flower were estimated. Plant communities were determined after Matuszkiewicz (2006) and nomenclature - after Mirek et al. (2002) and Ochyra et al. (2003).

\section{Results}

The population of $P$. patens (coverage from $\mathrm{r}$ to + ) near Wyszków grows on an escarpment of a railway embankment. The area is situated at the edge of a fresh Peucedano-Pinetum pine forest with elements of mixed forest. In the tree stand of crown density of $70 \%$, a layer $\mathrm{a}_{1}$ is built by Pinus sylvestris $\mathrm{L}$., and layer $\mathrm{a}_{2}-$ by Quercus robur L. (coverage of both species equals 2) with a smaller contribution of Betula pendula Roth (Table 1). Layer b (crown density $=50 \%$ ) is built by saplings of: Pinus sylvestris L. ${ }^{(2-1)}$, Quercus robur ${ }^{(1-2)}$, Populus tremula L. $^{(+-1)}$, Betula pendula ${ }^{(+-1)}$ and shrubs: Sorbus aucuparia L. em Hedl.(1) and Juniperus communis L. ${ }^{(1-2)}$. The undergrowth layer (density 70-80 $\%$ ) is quite variable. Apart from species characteristic for the Vaccinio-Picetea (Vaccinium myrtillus L. ${ }^{(1-2)}, V$. vitis-idaea $\mathrm{L}^{\left({ }^{(2)}\right)}$ class, there are species characteristic and differential for fresh Peucedano-Pinetum pine forests (for example: Solidago virgaurea L. ${ }^{(1)}$, Polygonatum odoratum (Mill.) Druce ${ }^{(+-1)}$, Convallaria majalis L. $^{(1-2)}$ and Scorzonera humilis L. $\left.{ }^{(\mathrm{r}-)}\right)$, heathlands of the Nardo-Callunetea class (i.a.: Calluna vulgaris (L.) Hull ${ }^{(1-2)}$, Hieracium pilosella L. ${ }^{(2-3)}$, Dantonia decumbens DC. $\left.{ }^{(1)}\right)$, thermophilous marginal species of the Trifolio-Geranietea class (e.g. Geranium sanguineum $\mathrm{L}^{(\mathrm{r}-1)}$, Peucedanum oreoselinum (L.) Moench $^{(\mathrm{r}-+)}$ and Anthericum ramosum $\mathrm{L}^{(+)}$) and dry sandy meadows of the Koelerio-Corynophoretea class (for example, Festuca ovina L. ${ }^{(+-1)}$, Thymus serpyllum L. em Fr. ${ }^{(+-1)}$, Corynephorus canescens (L.) P. Beauv. ${ }^{(+-1)}$ and Rumex acetosella $\left.\mathrm{L}^{(+-1)}\right)$. In the group of accompanying species, those of the largest coverage include: Calamagrostis epigejos (L.) Roth ${ }^{(1-2)}$, Poa pratensis L. ${ }^{(+-2)}$, Agrostis capillaris $\mathrm{L}^{(+-3)}$. The moss layer of $60-70 \%$ density is mainly built by Pleurozium schreberi (Willd. ex Brid.) Mitt. ${ }^{(3-4)}$, Dicranum undulatum Schrad. ex Brid. ${ }^{(2-3)}$ and lichens of the Cladonia ${ }^{(1-2)}$ genus.

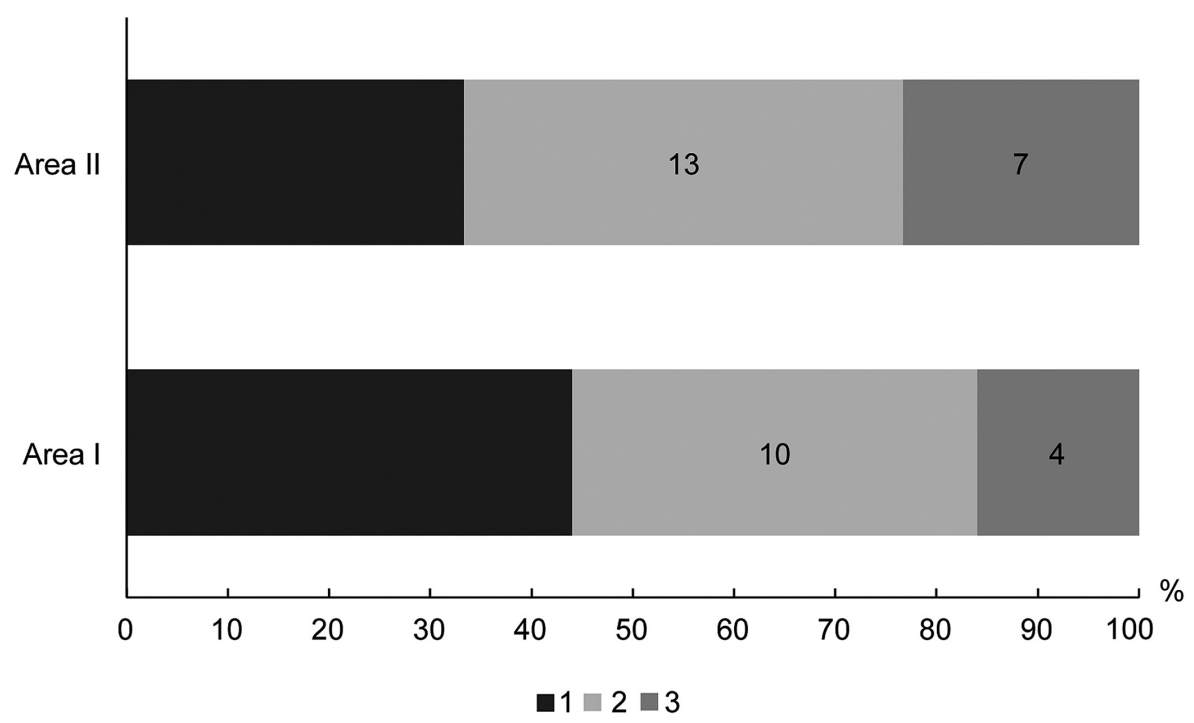

Fig. 2. Frequency of occurrence of flora accompanying Pulsatilla patens on the permanent study plots Explanations: 1 - constant level, 2 - increasing frequency, 3 - decreasing frequency 
Table 1. Phytosociological characteristics of the Pulsatilla patens locality in Dalekie near Wyszków

\begin{tabular}{|c|c|c|c|c|}
\hline \multicolumn{2}{|l|}{ Date of the relevé } & 12.06 .2008 & 15.05 .2011 & 20.06 .2014 \\
\hline \multicolumn{2}{|l|}{ Surface area $\mathrm{m}^{2}$} & 100 & 100 & 100 \\
\hline \multicolumn{2}{|l|}{ Layer density a $\quad \%$} & 70 & 70 & 70 \\
\hline \multicolumn{2}{|l|}{ Layer density b $\%$} & 50 & 50 & 50 \\
\hline \multicolumn{2}{|l|}{ Layer density c $\%$} & 70 & 70 & 80 \\
\hline \multicolumn{2}{|l|}{ Layer density d $\%$} & 70 & 70 & 60 \\
\hline \multicolumn{2}{|l|}{ Number of species } & 39 & 38 & 48 \\
\hline \multicolumn{5}{|l|}{ Trees and shrubs } \\
\hline Pinus sylvestris & $\mathrm{a}$ & 2 & 2 & 2 \\
\hline Pinus sylvestris & $\mathrm{b}$ & 2 & 2 & 1 \\
\hline Pinus sylvestris & $\mathrm{c}$ & 1 & 1 & + \\
\hline Quercus robur & $a^{2}$ & 2 & 2 & 2 \\
\hline Quercus robur & $\mathrm{b}$ & 1 & 2 & 2 \\
\hline Quercus robur & $\mathrm{c}$ & 1 & 1 & + \\
\hline Populus tremula & $\mathrm{b}$ & + & 1 & 1 \\
\hline Populus tremula & $\mathrm{c}$ & + & 1 & + \\
\hline Betula pendula & $a^{2}$ & 1 & 1 & 1 \\
\hline Betula pendula & $\mathrm{b}$ & + & 1 & + \\
\hline Betula pendula & $\mathrm{c}$ & + & + & . \\
\hline Sorbus aucuparia & $\mathrm{b}$ & 1 & 1 & 1 \\
\hline Sorbus aucuparia & $\mathrm{c}$ & + & + & + \\
\hline Juniperus communis & $\mathrm{b}$ & 1 & 2 & 1 \\
\hline Juniperus communis & $\mathrm{c}$ & + & 1 & 1 \\
\hline Tilia cordata & $\mathrm{c}$ & . & . & $\mathrm{r}$ \\
\hline Padus serotina & $\mathrm{c}$ & . & . & $\mathrm{r}$ \\
\hline Chamaecytisus ratis & bonensis c & + & . & 1 \\
\hline Pulsatilla patens & & $\mathrm{r}$ & + & + \\
\hline
\end{tabular}

Ch.D. Vaccinio-Picetea

Cladonia arbuscula

Cladonia rangiferina

Pleurozium schreberi

Dicranum undulatum

Vaccinium myrtillus

Vaccinium vitis-idaea

Trientalis europaea

Melampyrum pratense

Polytrichum commune

Ch.D. Peucedano-Pinetum

Convallaria majalis

Solidago virgaurea

Polygonatum odoratum

Scorzonera humilis

Peucedanum oreoselinum

Geranium sanguineum

Anthericum ramosum

Rubus saxatilis

Ch.D. Nardo-Callunetea

Calluna vulgaris

Hieracium pilosella

Danthonia decumbens

Carex ericetorum

Viola canina

Ch.D. Koelerio-Corynephoretea

Festuca ovina

Thymus serpyllum

Corynephorus canescens

Rumex acetosella

Helichrysum arenarium 


\begin{tabular}{lccc}
\hline Date of the relevé & 12.06 .2008 & 15.05 .2011 & 20.06 .2014 \\
Surface area $\mathrm{m}^{2}$ & 100 & 100 & 100 \\
Layer density a \% & 70 & 70 & 70 \\
Layer density b \% & 50 & 50 & 50 \\
Layer density c \% & 70 & 70 & 80 \\
Layer density d \% & 70 & 70 & 60 \\
Number of species & 39 & 38 & 48 \\
\hline Accompanying: & & & \\
Calamagrostis epigejos & 2 & 1 & 1 \\
Luzula pilosa & 1 & 1 & + \\
Hieracium murorum & 1 & 1 & + \\
Anthoxanthum odoratum & 1 & 1 & + \\
Poa pratensis & + & 2 & 1 \\
Hieracium lachenalii & + & + & 1 \\
Galium boreale & + & + & 1 \\
Agrostis capillaris & + & + & 3 \\
Impatiens parviflora &. &. & $\mathrm{r}$ \\
Fragaria vesca &. &. & $\mathrm{r}$ \\
Pimpinella saxifraga &. &. & $\mathrm{r}$ \\
\hline
\end{tabular}

The number of species present in patches together with the pasque-flower increased during 7 years (Table 1) from 39 in 2008 to 48 in 2014. The density of undergrowth increased by $10 \%$. Young individuals of trees and shrubs like: Tilia cordata Mill., Padus serotina (Ehrh.) Borkh., Juniperus communis, Chamaecytisus ratisbonensis (Schaeff.) Rothm. and Rubus saxatilis L. appeared in this period. Herbs were represented, among others, by: Helichrysum arenarium (L.) Moench, Impatiens parviflora DC. and Pimpinella saxifraga L. The coverage degree for Polytrichum commune Hedw. was 2 according to the Braun-Blanquet scale. The species occurred in layer d in 2014.

Floristic analysis in $2 \times 2 \mathrm{~m}$ plots in close neighbourhood of $P$. patens clumps showed an increase in the number of accompanying species (Table 2). The number of taxa in plot I increased from 19 to 25 (by $31.5 \%$ ) and in plot II - from 24 to 30 (by $25 \%$ ) during 7 years. New species of trees and shrubs appeared in both plots: Quercus robur (plots I and II), Juniperus communis (plot II) and Chamaecytisus ratisbonensis (plot I). In the last year, Rumex acetosella, Thymus serpyllum and Anthoxanthum odoratum L. appeared for the first time in plot I and Convallaria majalis, Polygonatum odoratum and Hieracium murorum L. appeared in plot II (Table 2). Species increasing their numbers were an important group of plants (10 species in plot I and 13 species in plot II) (Fig. 2).

P. patens population near Wyszków showed increasing trends (Table 3). The number of pasque-flower shoots increased from 3 in 2008 to 11 in 2015. The greatest number of shoots was observed in 2012 (16 shoots). In five studied periods, $P$. patens occurred only in vegetative stage. Only between 2011 and 2013, generative shoots were noted (1-2 specimens). The number of leaves varied from year to year. The highest mean number of leaves per one shoot of 7.0 was noted in 2009 and 2014. The lowest mean number of leaves (4.0) was recorded in 2012 (Table 3). The highest number of leaves on a shoot (14) was observed in 2014 and the lowest (1) - in 2012.

\section{Discussion}

P. patens population in Dalekie near Wyszków was not numerous and consisted of a dozen or so shoots, usually occurring in vegetative stage (only in three years of studies, flowering shoots were observed).

It was found on an escarpment at the edge of fresh Peucedano-Pinetum pine forest with elements of mixed Serratulo-Pinetum pine forest and steppe Potentillo albae-Quercetum oak forest. The pasque-flower from similar sites was also reported by Juśkiewicz-Swaczyna (2010a), Sokołowski (1991) and Pawlikowski (2011).

$P$. patens prefers open and sunlit places. Uotila $(1969,1996)$, in the study on P. patens ecology in Finland, concluded that individuals grew better in open places like clear cuttings, firebreaks and forest paths. Photic conditions in the study area were good. Clumps were located in open areas, on railway embankments near a fresh pine forest. No individuals of the pasqueflower were, however, found in more shadowed areas inside the forest. The population was negatively affected 
Table 2. Species accompanying Pulsatilla patens in the locality Dalekie near Wyszków

\begin{tabular}{|c|c|c|c|c|c|}
\hline \multirow[b]{2}{*}{ Date of the relevé } & & \multicolumn{2}{|c|}{ Area I } & \multicolumn{2}{|c|}{ Area II } \\
\hline & & 15.05.2008 & 12.06 .2014 & 15.05.2008 & 12.06 .2014 \\
\hline Surface area $\mathrm{m}^{2}$ & & 4 & 4 & 4 & 4 \\
\hline Layer density $b \quad \%$ & & 10 & 10 & - & 10 \\
\hline Layer density c $\quad \%$ & & 50 & 60 & 50 & 60 \\
\hline Layer density d $\%$ & & 100 & 70 & 100 & 80 \\
\hline Number of species & & 19 & 25 & 24 & 30 \\
\hline \multicolumn{6}{|l|}{ Trees and shrubs: } \\
\hline Juniperus communis & $\mathrm{b}$ & 1 & 1 & . & 1 \\
\hline Juniperus communis & $\mathrm{c}$ & . & + & . & + \\
\hline Chamaecytisus ratisbonensis & $\mathrm{c}$ & . & 1 & + & 1 \\
\hline Quercus robur & $\mathrm{c}$ & . & 1 & . & + \\
\hline Pulsatilla patens & & 1 & 1 & + & + \\
\hline \multicolumn{6}{|l|}{ Ch.D. Vaccinio-Picetea } \\
\hline Cladonia arbuscula & & 1 & 1 & 1 & + \\
\hline Cladonia rangiferina & & 1 & 1 & 2 & 1 \\
\hline Dicranum undulatum & & 5 & 3 & 3 & 3 \\
\hline Pleurozium schreberi & & 2 & 3 & 2 & 3 \\
\hline Vaccinium vitis-idaea & & 2 & 2 & 2 & 2 \\
\hline Polytrichum commune & & . & . & 1 & 2 \\
\hline \multicolumn{6}{|l|}{ Ch.D. Peucedano-Pinetum } \\
\hline Peucedanum oreoselinum & & + & $\mathrm{r}$ & + & + \\
\hline Scorzonera humilis & & + & + & + & + \\
\hline Solidago virgaurea & & $\mathrm{r}$ & + & + & + \\
\hline Convallaria majalis & & $\mathrm{r}$ & + & . & 1 \\
\hline Polygonatum odoratum & & 1 & + & . & 1 \\
\hline Anthericum ramosum & & . & . & $\mathrm{r}$ & + \\
\hline Geranium sanguineum & & . & . & $\mathrm{r}$ & + \\
\hline \multicolumn{6}{|l|}{ Ch.D. Nardo-Callunetea } \\
\hline Calluna vulgaris & & 1 & + & 1 & + \\
\hline Danthonia decumbens & & 1 & + & + & + \\
\hline Hieracium pilosella & & 1 & 2 & 2 & 1 \\
\hline Carex ericetorum & & $\mathrm{r}$ & + & & \\
\hline \multicolumn{6}{|c|}{ Ch.D. Koelerio-Corynephoretea } \\
\hline Festuca ovina & & 2 & 2 & 2 & 1 \\
\hline Rumex acetosella & & . & + & $\mathrm{r}$ & + \\
\hline $\begin{array}{l}\text { Thymus serpyllum } \\
\text { Accompanying: }\end{array}$ & & . & + & + & + \\
\hline Calamagrostis epigejos & & 1 & 1 & 1 & + \\
\hline Poa pratensis & & + & 1 & 1 & + \\
\hline Anthoxanthum odoratum & & . & + & + & + \\
\hline Galium boreale & & . & . & $\mathrm{r}$ & + \\
\hline Taraxacum officinale & & . & . & $\mathrm{r}$ & . \\
\hline Hieracium murorum & & . & . & . & + \\
\hline Hieracium lachenalii & & . & . & . & + \\
\hline
\end{tabular}

by excessive development of undergrowth and moss layer. According to Röder and Kiehl (2006), substantial cover by seed plants and the presence of litter negatively affects the number of seedlings. Wójtowicz (2004), and Pilt \& Kukk (2002) state that sprouting of the pasque- flower seeds is effective in open places free from other competing plants.

The reason of the declining number of the pasqueflower clumps in Dalekie and, at the same time, the greatest risk was the excavation of sand from the escarp- 
Table 3. Morphological parameters of Pulsatilla patens in the locality Dalekie near Wyszków

\begin{tabular}{cccccc}
\hline \multirow{2}{*}{ Year } & \multirow{2}{*}{$\begin{array}{c}\text { Number } \\
\text { of shoots }\end{array}$} & $\begin{array}{c}\text { Number of flowering } \\
\text { individuals }\end{array}$ & $\begin{array}{c}\text { Number } \\
\text { of leaves }\end{array}$ & \multicolumn{2}{c}{ Number of leaves on one shoot } \\
\cline { 5 - 6 } 2008 & 3 & - & 14 & range & mean \\
2009 & 6 & - & 42 & $4-12$ & 4.7 \\
2010 & 7 & - & 44 & $3-13$ & 7.0 \\
2011 & 9 & 1 & 44 & $2-10$ & 6.3 \\
2012 & 16 & 2 & 63 & $1-11$ & 5.0 \\
2013 & 10 & 1 & 51 & $2-10$ & 4.0 \\
2014 & 7 & - & 49 & $2-14$ & 7.1 \\
2015 & 11 & - & 51 & $2-10$ & 4.6 \\
\hline
\end{tabular}

ment. In 2012, the escarpment slid down and several clumps of the pasque-flower were destroyed. Further sand excavation may lead to complete destruction of the site.

An additional factor that may hamper the population is forest works and digging by wild boars. Cut down tree limbs and branches were observed lying in the site, which was associated with cutting and destruction of the undergrowth layer when carrying timber away.

To preserve the site of P. patens, measures of active protection should be applied . Based on recommendations given in Methodological Guide (Pawlikowski 2012), it is necessary to remove expansive plants in order to maintain optimum photic condition in sites of the pasque-flower. Impatiens parviflora appeared in one of the study plots. Parthenocissus quinquefolia (L.) Planch. in A \& C. DC. was also observed nearby. Forest rangers should pay attention to these two species that might pose a threat to the population.

\section{Conclusions}

Based on our study, the following conclusions may be formulated:

New site of P. patens in Dalekie near Wyszków is situated on an escarpment of the railway embankment in fresh Peucedano-Pinetum pine forest with elements of mixed pine forest and steppe oak forest. These are typical habitat conditions for this species.

Now the population of $P$. patens consists of 11 individuals. During the first five years (2008-2012), the populations showed an increasing trend. Recently, it has stabilised.

Destruction of the escarpment (sand excavation), forest works and digging by wild boars are responsible for changes in population density.

To protect the population, it is necessary to eliminate the above-mentioned factors and remove expansive species (Impatiens parviflora, Parthenocissus quinquefolia) growing together with the pasque-flower.

\section{References}

Chmura D. 2003. Zagrożenia lokalnych populacji sasanki otwartej Pulsatilla patens na przykładzie stanowiska na Sodowej Górze. Chrońmy Przyr. Ojcz. 59(5): 14-27.

Cioser M. T. 1985. Materiały do flory Podlasia i Mazowsza. Zesz. Nauk WSR-P Siedlce. 4: 137-156.

Ciosek M. T. 1990. Materiały do flory Puszczy Białej. Zesz. Nauk. WSR-P Siedlce. 24: 59-74.

Ciosek M. T. 1995a. Materiały do flory Puszczy Białej. Okolice Ostrowi Mazowieckiej. Zesz. Nauk. WSR-P Siedlce. 44: 29-33.

Ciosek M. T. 1995b. Rzadkie i chronione gatunki roślin okolic Ostrołęki. Zesz. Nauk. WSR-P Siedlce. 44: 35-40.

Ciosek M. T. 1999. Rodzaj Pulsatilla (Ranunculaceae) na Podlasiu i Mazowszu. Fragm. Flor. Geobot. Polonica 6: $15-19$
GŁowacki Z., Falkowski M., Krechowski J., Marciniuk J., Marciniuk P., Nowicka-Falkowska K. \& Wierzba M. 2003. Czerwona lista roślin naczyniowych Niziny Południowopodlaskiej. Chrońmy Przyr. Ojcz. 59(2): 5-41.

Grulich V. 2012. Red List of vascular plants of the Czech Republic: 3rd edition. Preslia 84: 631-645.

Jackowiak B., Celka Z., Chmiel J., Latowski K. \& Żukowski W. 2007. Red list of vascular flora of Wielkopolska (Poland). Biodiv. Res. Conserv. 5-8: 95-127.

JuŚKIEWICZ-SwACZYNA B. 2010a. Distribution and abundance of Pulsatilla patens populations in nature reserves in North-Eastern Poland. Pol. J. Natur. Sc. 25: 376-386.

JuśKIEWICZ-SwACZynA B. 2010b. Population structure of Pulsatilla patens in relation to the habitat quality. Tuexenia 30: 457-466. 
Kalliovirta M., KukK Ü. \& Ryttäri T. 2003. Pulsatilla patens (L.) Mill. In: T. RytTÄRI, Ü. KuKK, T. KulL, A. JÄKÄLÄNIEMI, M. ReItAlu (eds.). Monitoring of threatened vascular plants in Estonia and Finland methods and experiences. Finn. Environ. 659: 37-47.

Kondracki J. 2013. Geografia regionalna Polski. 444 pp. Wyd. Nauk. PWN, Warszawa.

Łaska G. \& Sienkiewicz A. 2010. Eastern Pasque flower Pulsatilla patens (L.) Mill. in the Knyszyńska Forest. Acta Soc. Bot. Pol. 79: 46-47.

Markowski R. \& Buliński M. 2004. Ginące i zagrożone rośliny naczyniowe Pomorza Gdańskiego. Acta Bot. Cassub. Monogr. 1: 1-75.

Matuszkiewicz W. 2006. Przewodnik do oznaczania zbiorowisk roślinnych Polski. In: J. B. FALiński (ed.). Vademecum Geobotanicum 3, 537 pp. Wyd. Nauk. PWN, Warszawa.

Meusel H., Jäger E. \& Weinert E. 1965. Vergleichende Chorologie der zentraleuropäischen Flora. I. Text 583 pp., Karten 258 pp. Gustav Fischer Verlag, Jena.

Mirek Z., Piękoś-Mirkowa H., Zając A. \& Zając M. 2002. Flowering plants and pteridophytes of Poland. A checklist. In: Z. MireK (ed.). Biodiversity of Poland, 1, 442 pp. W. Szafer Institute of Botany, Polish Academy of Sciences, Kraków.

Ochyra R., Żarnowiec J. \& Bednarek-Ochyra H. 2003. Census Catalogue of Polish Mosses. In: Z. Mirek (ed.). Biodiversity of Poland, 3, $372 \mathrm{pp}$. Polish Academy of Sciences, Institute of Botany, Kraków.

PAwlikowski P. 2011. Pulsatilla patens - sasanka otwarta. Monitoring gatunków i siedlisk przyrodniczych ze szczególnym uwzględnieniem specjalnych obszarów ochrony siedlisk Natura 2000. Wyniki monitoringu GIOŚ.

Pawlikowski P. 2012. Sasanka otwarta Pulsatilla patens (1477). Monitoring gatunków i siedlisk przyrodniczych ze szczególnym uwzględnieniem specjalnych obszarów ochrony siedlisk Natura 2000. Wyniki monitoringu.

Pawlikowski P. \& Wóstowicz W. 2014. Pulsatilla patens (L.) Mill. - Sasanka otwarta. In: R. KAźmierczAKowa, K. ZARZYCKi \& Z. MireK (eds.). Polska Czerwona Księga Roślin, Paprotniki i rośliny kwiatowe, wyd. 3 uaktualnione i rozszerzone, pp. 186-188. PAN, Instytut Ochrony Przyrody, Kraków.

PILt I. \& KUKK Ü. 2002. Pulsatilla patens and Pulsatilla pratensis (Ranunculaceae) in Estonia: distribution and ecology. Proc. Eston. Acad. Sci. Biol. Ecol. 51: 242-256.
RÖDER D. \& KIEHL K. 2006. Population structure and population dynamic of Pulsatilla patens (L.) Mill. in relation to vegetation characteristics. Flora 201: 499-507.

Romer E. 1949. Regiony klimatyczne Polski. Prace Wrocławskiego Towarzystwa Naukowego, Ser. B. 16: $1-28$.

SokoŁowski A. W. 1991. Roślinność rezerwatu Sitki w Puszczy Białowieskiej. Ochrona Przyrody 48: 85-103.

Trampler T., Kliczkowska A., Dmytreko E. \& Sierpińska A. 1990. Regionalizacja przyrodniczo-leśna na podstawach ekologiczno-fizjograficznych. 155 pp. PWRiL Warszawa.

Uotila P. 1969. Ecology and area of Pulsatilla patens (L.) Mill. in Finland. Ann. Bot. Fenn. 6: 105-111.

Uotila P. 1996. Decline of Anemone patens (Ranunculaceae) in Finland. Acta. Univ. Ups. Symb. Bot. Ups. 31: 205-210.

Wóstowicz W. 2000. Biologia, wymagania siedliskowe i możliwości uprawy zachowawczej Pulsatilla patens (L.) Mill. Biul. Ogr. Bot. 9: 45-54.

Wójtowicz W. 2001. Pulsatilla patens (L.) Mill. - Sasanka otwarta. In: K. ZARZYCKI \& R. KAŹMIERCZAKOWA (eds.). Polska Czerwona Księga Roślin, Paprotniki i rośliny kwiatowe, wyd. 2, pp. 142-144. PAN, Instytut Botaniki im. W. Szafera, Instytut Ochrony Przyrody, Kraków.

Wójtowicz W. 2004. Pulsatilla patens (L.) Mill. Sasanka otwarta. In: H. Werblan-Jakubiec \& B. SudniKWóJCIKowska (eds.). Poradnik ochrony siedlisk i gatunków Natura 2000, 9: 168-171.

ZajĄC A. \& ZajĄC M. (eds.). 2001. Distribution Atlas of Vascular Plants in Poland. xii+714 pp. Edited by Laboratory of Computer Chorology, Institute of Botany, Jagiellonian University, Cracow.

ZARZYCKI K. \& SZELĄG Z. 2006. Red list of the vascular plants in Poland. In: Z. Mirek, K. Zarzycki, W. WojewodA \& Z. Szeląg (eds.). Red list of plants and fungi in Poland, pp. 9-20. W. Szafer Institute of Botany, Polish Academy of Sciences, Kraków.

ZYCH M. 2007. Krajowy Plan Ochrony Gatunku. Sasanka otwarta Pulsatilla patens (L.) Mill. 36 pp. Warszawa.

ŻUKOWsKi W. \& JACKOWIAK B. 1995. List of endangered and threatened vascular plants in Western Pomerania and Wielkopolska (Great Poland). In: W. Żukowski \& B. JACKOWIAK (eds.). Endangered and threatened vascular plants of Western Pomerania and Wielkopolska. Publications of the Department of Plant Taxonomy of the Adam Mickiewicz University in Poznań 3: 9-96. Bogucki Wyd. Nauk., Poznań. 